\title{
Biochemistry of the plasmin system
}

\author{
D OGSTON
}

From the Department of Physiology, University of Aberdeen, Aberdeen, Scotland

The fibrinolytic enzyme system is designed to release the protease plasmin from its inactive precursor plasminogen and to localise its action to the site of its physiological substrate fibrin. The basic components of the system are, therefore, plasminogen and plasmin; agents, collectively termed plasminogen activators, which convert plasminogen to plasmin; and inhibitors of activators or plasmin which ensure that proteolysis of other susceptible proteins does not take place. This review considers the structure and properties of plasminogen and plasmin and the processes involved in the activation of plasminogen, and outlines their relationship to recent concepts of thrombolysis.

\section{Plasminogen}

SYNTHESIS AND METABOLISM

The plasma concentration of plasminogen is around $200 \mu \mathrm{g} / \mathrm{ml}^{1{ }^{12}}$ Its half-life in healthy men is between 1.75 and 2.65 days. ${ }^{2}$ A rapid rate of synthesis is inferred from the restoration of normal plasma concentrations within 12-24 hours of depletion during thrombolytic therapy with streptokinase.

The site of synthesis of plasminogen has not been established. Using a fluorescent antibody technique Barnhart and Riddle ${ }^{3}$ concluded that plasminogen is synthesised in bone marrow eosinophils. All types of human granulocytes have subsequently been found to contain a high concentration of plasminogen ${ }^{4}$ while treatment of leucocytes with cytostatic agents was observed to result in the disappearance of the plasminogen, suggesting that the granulocytes may be a site of synthesis. ${ }^{5}$ The liver, shown to be the site of formation of the $\alpha$ - and $\beta$-globulins, ${ }^{6}$ has not been excluded as a source of the $\beta$-globulin plasminogen, and the kidney may be a further source. ${ }^{?}$

\section{STRUCTURE AND PROPERTIES}

Human plasminogen is a single-chain glycoprotein with 791 amino-acid residues. ${ }^{8}$ It was initially believed to have lysine as the $\mathrm{NH}_{2}$-terminal aminoacid, ${ }^{9}$ but it was found subsequently that native plasminogen has glutamic acid rather than lysine in the $\mathrm{NH}_{2}$-terminal position. ${ }^{10}$ It is now clear that plasminogen with $\mathrm{NH}_{2}$-terminal lysine (lys-plasminogen) results from proteolytic degradation of the native form (glu-plasminogen) with removal of peptide material from this part of the molecule during preparation. The $\mathrm{COOH}$-terminal amino-acid is asparagine. ${ }^{9}$ Based on the amino-acid composition and assuming a carbohydrate content of $1.5 \%$ the molecular weight of glu-plasminogen would be about 90000.11 Through the endeavours of a number of laboratories the primary structure of plasminogen is now known. 8

A variety of physicochemical findings have shown conformational differences between the glu- and lysforms of plasminogen. Circular dichroism spectra in the near ultraviolet region differ significantly 12 and sedimentation analysis has also indicated differing conformational states. ${ }^{13}$

Apart from glu- and lys-plasminogen a number of different molecular forms of plasminogen have been demonstrated by electrophoretic techniques. ${ }^{1014}$ Using affinity chromatography on lysine-Sepharose both glu- and lys-plasminogen have been separated into two forms with differing molecular size and charge. ${ }^{15}$ The cause of the microheterogeneity is uncertain; sialic acid content differences may contribute. ${ }^{16}$

\section{Lysine-binding sites}

Structures in plasminogen which specifically bind omega amino-acids such as lysine and 6-aminohexanoic acid are termed the lysine-binding sites. Plasminogen forms a 1:1 stoichiometric complex with these amino-acids ${ }^{17}$ with the production of striking conformational changes in the plasminogen molecule ${ }^{1218}$ - changes seen also on the conversion of glu- to lys-plasminogen. There are several lysinebinding sites on plasminogen, one with high affinity and four or five with low affinity for 6-aminohexanoic acid. ${ }^{19}$ The site which strongly binds 6-aminohexanoic acid is located in the $\mathrm{NH}_{2}$-terminal part of the molecule ${ }^{20}$ and the conformational change is believed to arise from the dissociation of a noncovalent interaction between a site in the $\mathrm{NH}_{2-}$ terminal part and a lysine-binding site elsewhere in the molecule. ${ }^{21}$

There has been debate over the years whether 


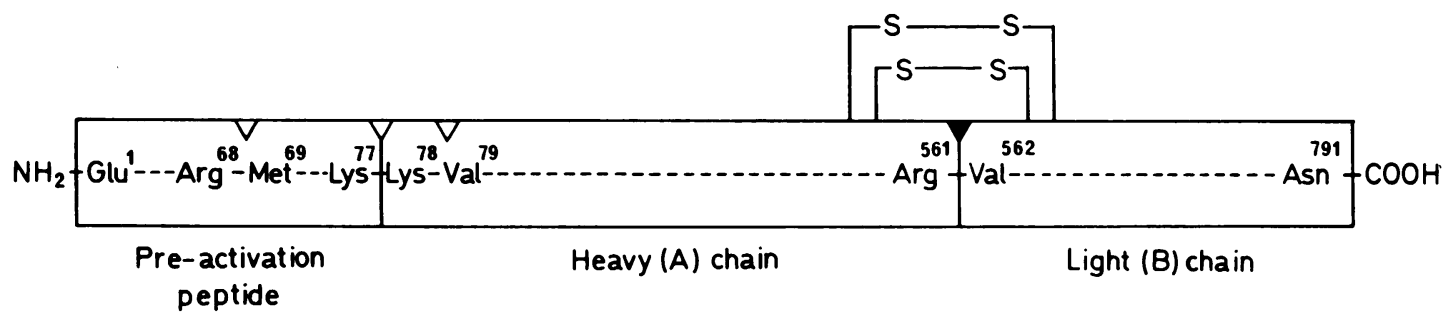

Fig. 1 Gross structural features of human plasminogen to plasmin conversion. $\nabla$ Site cleaved by activator. $\nabla$ Sites cleaved by plasmin.

plasminogen is specifically adsorbed to fibrin. There is now substantial evidence that such adsorption does take place and that the quantities involved, although relatively small, are of functional significance. Lys-plasminogen is adsorbed to fibrin more efficiently than glu-plasminogen. ${ }^{22} 23$ In recently described experiments some $4 \%$ of native plasma plasminogen (glu-plasminogen) binds to fibrin compared with $8 \%$ for lys-plasminogen. ${ }^{23}$ The only fragments of plasminogen which adsorb to fibrin are those which also adsorb to lysine-Sepharose, indicating a likely identity between lysine-binding sites and the sites responsible for the association of plasminogen with fibrin. ${ }^{20}$

Fibrinogen contains several sites which can interact with the lysine-binding sites in plasminogen. These are present in purified fragment $\mathrm{E}$ and fragment $\mathrm{D}$ demonstrating location in both the $\mathrm{NH}_{2}$-terminal and $\mathrm{COOH}$-terminal regions of fibrinogen. ${ }^{24}$

Lysine-binding sites on plasminogen are also involved in the interaction of plasmin with the fastacting $\alpha_{2}$-antiplasmin. ${ }^{24}$

\section{ACTIVATION}

Some features of the human plasminogen to plasmin conversion are represented in Fig. 1. The activation of plasminogen by urokinase requires the cleavage of a specific sensitive arginyl-valyl peptide bond $\left(\mathrm{Arg}_{561}\right.$-Val) in the COOH-terminal portion of the molecule with the production of a two-chain molecule. ${ }^{25}$ While there is universal agreement on the requirement for hydrolysis of this bond subsequent studies have suggested that the activation of plasminogen is a two-step mechanism. In the first step it was proposed that a peptide bond in the $\mathrm{NH}_{2}-$ terminal part of the glu-plasminogen molecule is cleaved leaving Met 69 as the $\mathrm{NH}_{2}$-terminal aminoacid. ${ }^{26}$ In the second step cleavage of the arginylvalyl bond takes place as originally described. Finally, further proteolysis in the $\mathbf{N H}_{2}$-terminal portion of the Lys7z-Lys bond results in the formation of lys-plasmin. More recently it has been shown that the only bond cleaved by urokinase in the presence of the plasma plasmin inhibitors or Trasylol

\section{is $\mathrm{Arg}_{561}-\mathrm{Val}^{27} 28$}

In the absence of specific inhibitors a second bond is cleaved, Arg 68 -Met or Lys77-Lys. It is now accepted that these cleavages in the $\mathrm{NH}_{2}$-terminal part of the molecule are due to plasmin rather than to activator. ${ }^{8}$ While splitting of the Arg $_{561}$-Val bond in glu-plasminogen alone provides a plasmin molecule with protease activity the activation rate of lys-plasminogen, formed by the cleavage of the plasmin-sensitive bonds in the $\mathbf{N H}_{2}$-terminal part of the molecule, is many times faster. ${ }^{29}$

Probably the increased rate of activation of lys-plasminogen is determined by the conformation change which follows the release of peptide material (preactivation peptide) from the $\mathrm{NH}_{2}$-terminus, a conformational change which is also induced by the addition of omega amino-acids. The conformational change resulting from removal of the preactivation peptide may, by uncovering fibrin-binding sites, be responsible also for the more efficient adsorption of lys-plasminogen to fibrin.

The precise pathway for the activation of plasminogen is not finally established. One possibility which takes account of much of the experimental findings is represented diagrammatically in Fig. 2. The initial event in this scheme is the formation of catalytic quantities of glu-plasmin from glu-plasminogen by the action of activator on the $\mathrm{Arg}_{561}-\mathrm{Val}$ bond. The plasmin formed cleaves the preactivation peptide from the $\mathrm{NH}_{2}$-terminal portion of the molecule to form lys-plasminogen, and the accompanying conformational change facilitates its further cleavage by activator and the formation of the two-chain lys-plasmin molecule. This is essentially

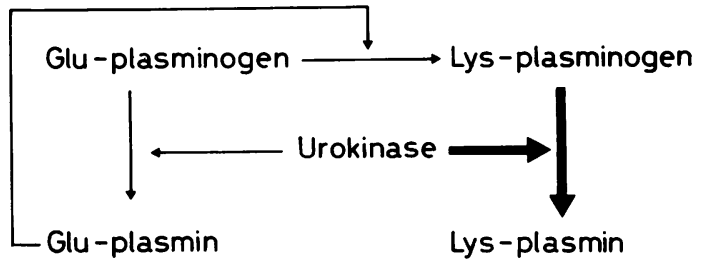

Fig. 2 Scheme for pathway of activation of plasminogen. 
the pathway proposed by Violand and Castellino. ${ }^{30}$ Lys-plasmin is the usual final form in activation systems in vitro, but the physiological form of plasmin has not been ascertained.

\section{Plasmin}

\section{STRUCTURE AND PROPERTIES}

Plasmin is a proteolytic enzyme with trypsin-like specificity which cleaves proteins and peptides at arginyl and lysyl bonds, ${ }^{31}$ basic amino esters, ${ }^{32}$ and amides. ${ }^{33}$ It appears to have a preference for lysyl bonds. ${ }^{34}$

Plasmin consists of two polypeptide chains, the heavy (A) chain and the light (B) chain, ${ }^{9}$ connected by two interchain disulphide bridges. ${ }^{35}$ The molecular weight of the heavy chain from the $\mathrm{NH}_{2}$-terminal part of the plasminogen molecule has been estimated at around $60000,{ }^{26}$ and the light chain from the $\mathrm{COOH}$-terminal end has a molecular weight of about $25000 .{ }^{36}$ The primary structure of the heavy chain of human plasmin has been established by Sottrup-Jensen and colleagues, ${ }^{37}$ while Wiman ${ }^{35}$ has detailed the primary structure of the light chain.

The active centre of plasmin contains a DFPsensitive serine residue and a single TLCK-sensitive histidine residue; both are sited on the light chain of the molecule. ${ }^{36}$

Plasmin is a protease of broad specificity. A number of plasma proteins are susceptible to its proteolytic action including coagulation factors $\mathrm{V}$ and VIII;3839 components of the complement system; 40 the hormones ACTH, glucagon, and somatotrophin; ${ }^{41}$ and, in purified systems, fibrinogen is also digested. Its principal physiological substrate is presumed, however, to be fibrin.

\section{Mechanism of thrombolysis}

The recent accumulation of knowledge on the biochemistry of plasminogen and its activation together with the concurrent discovery of the fastacting $\alpha_{2}$-antiplasmin has led to new concepts of the mechanism of thrombolysis. ${ }^{42}$

The principal physiological activator is probably that derived from the vascular wall. This activator is identical or closely similar to tissue activator, ${ }^{43}$ which has been shown to be strongly adsorbed to fibrin. ${ }^{22}$ Through its lysine-binding sites plasminogen is adsorbed to specific sites on fibrinogen and is therefore present on the fibrin formed from it. In addition, plasminogen may have a somewhat higher affinity for fibrin than for fibrinogen. In the presence of fibrin and its associated plasminogen the activating properties of tissue activator are much enhanced, ${ }^{44}$ leading to the rapid localised formation of plasmin at sites appropriate for the cleavage of fibrin. In-vitro studies have shown that the formation of lys-plasminogen with its associated conformational change increases its affinity for fibrin and makes it more readily activated. There is, however, no available evidence for the formation of the lys- form of plasminogen in the circulation. The physiological significance of this form of plasminogen is therefore uncertain.

When associated with fibrin the lysine-binding sites of plasmin are occupied and, as a result, its inactivation by $\alpha_{2}$-antiplasmin is very slow. In contrast, any free plasmin released into the plasma will be rapidly neutralised and the circulating fibrinogen and other susceptible proteins protected from proteolysis.

\section{References}

${ }^{1}$ Rabiner SF, Goldfine ID, Hart A, Summaria L, Robbins KC. Radioimmunoassay of human plasminogen and plasmin. J Lab Clin Med 1969;74: 265-73.

${ }^{2}$ Collen D, Tytgat G, Claeys H, Verstraete M, Wallén P. Metabolism of plasminogen in healthy subjects: effect of tranexamic acid. J Clin Invest 1972;51: 1310-8.

${ }^{3}$ Barnhart MI, Riddle JM. Cellular localisation of profibrinolysin (plasminogen). Blood 1963;21:306-21.

4 Prokopowicz J, Stormorken H. Fibrinolytic activity of leucocytes in smears of bone marrow and peripheral blood. Scand J Haematol 1968;5:129-37.

${ }^{5}$ Prokopowicz J, Rejniak L, Niewiarowski S. Influence of cytostatic agents on fibrinolytic and proteolytic enzymes and on phagocytosis of guinea-pig leucocytes. Experientia 1967;23:813-4.

${ }^{6}$ Miller LL, Bale WF. Synthesis of all plasma protein fractions except gamma globulins by the liver. Use of zone electrophoresis and lysine- $\sum-\mathrm{C}^{14}$ to define plasma proteins synthesised by the isolated perfused liver. J Exp Med 1954;99:125-32.

${ }^{7}$ Highsmith RF, Kline DL. Kidney: primary source of plasminogen after acute depletion in the cat. Science 1971;174:141-2.

${ }^{8}$ Wiman B. Biochemistry of the plasminogen to plasmin conversion. In: Gaffney PJ, Balkuv-Ulutin S, eds. Fibrinolysis: current fundamental and clinical concepts. London: Academic Press, 1978:47-60.

${ }^{9}$ Robbins KC, Summaria L, Hsieh B, Shah RJ. The peptide chains of human plasmin. Mechanism of activation of human plasminogen to plasmin. J Biol Chem 1967;242:2333-42.

10 Wallén P, Wiman B. Characterization of human plasminogen. I. On the relationship between different molecular forms of plasminogen demonstrated in plasma and found in purified preparations. Biochim Biophys Acta 1970;221 :20-30.

11 Wallén P. Chemistry of plasminogen and plasminogen activation. In: Davidson JF, Rowan RM, Samama MM, Desnoyers PC, eds. Progress in chemical 
fibrinolysis and thrombolysis, vol 3. New York: Raven Press, 1978:167-81.

12 Sjöholm I, Wiman B, Wallén P. Studies on the conformational changes of plasminogen induced during activation to plasmin and by 6-aminohexanoic acid. Eur J Biochem 1973;39:471-9.

13 Violand BN, Sodetz JM, Castellino FJ. The effect of $\epsilon$-amino caproic acid on the gross conformation of plasminogen and plasmin. Arch Biochem Biophys 1975;170:300-5.

14 Summaria L, Arzadon L, Bernabe P, Robbins KC. Studies on the isolation of the multiple molecular forms of human plasminogen and plasmin by isoelectric focusing methods. J Biol Chem 1972; 247:4691-702.

${ }^{15}$ Summaria L, Spitz F, Arzadon L, Boreisha G, Robbins KC. Isolation and characterization of the affinity chromatography forms of human glu- and lysplasminogens and plasmins. J Biol Chem 1976; 251 :3693-9.

${ }^{16}$ Collen D, de Maeyer L. Molecular biology of human plasminogen. I. Physicochemical properties and microheterogeneity. Thromb Diath Haemorrh 1975; 34:396-402.

${ }^{17}$ Abiko Y, Iwamoto M, Tomikawa M. Plasminogenplasmin system. V. A stoichiometric equilibrium complex of plasminogen and a synthetic inhibitor. Biochim Biophys Acta 1969;185:424-31.

${ }^{18}$ Alkjaersig N. The purification and properties of human plasminogen. Biochem J 1964;93:171-82.

${ }^{19}$ Markus G, De Pasquale JL, Wissler FC. Quantitative determination of the binding of $\epsilon$-aminocaproic acid to native plasminogen. $J$ Biol Chem 1978;253:727-32.

${ }^{20}$ Wiman B, Wallén P. The specific interaction between plasminogen and fibrin. A physiological role of the lysine binding site in plasminogen. Thromb Res 1977;10:213-22.

21 Wiman B, Wallén P. Structural relationships between 'glutamic acid' and 'lysine' forms of human plasminogen and their interaction with the $\mathrm{NH}_{2}$-terminal activation peptide as studied by affinity chromatography. Eur J Biochem 1975;50:489-94.

${ }^{22}$ Thorsen S. Differences in the binding to fibrin of native plasminogen and plasminogen modified by proteolytic degradation. Influence of $\omega$-aminocarboxylic acids. Biochim Biophys Acta 1975;393:55-65.

${ }^{23}$ Rákóczi I, Wiman B, Collen D. On the biological significance of the specific interaction between fibrin, plasminogen and antiplasmin. Biochim Biophys Acta 1978;540:295-300.

${ }^{24}$ Wiman B, Lijnen HR, Collen D. On the specific interaction between the lysine-binding sites in plasmin and complementary sites in $\alpha_{2}$-antiplasmin and in fibrinogen. Biochim Biophys Acta 1979;579:142-54.

${ }^{25}$ Robbins KC, Summaria L, Hsieh B, Shah RJ. The peptide chains of human plasmin. Mechanism of activation of human plasminogen to plasmin. $J$ Biol Chem 1967;242:2333-42.

${ }^{26}$ Wiman B, Wallén P. Activation of human plasminogen by an insoluble derivative of urokinase. Structural changes of plasminogen in the course of activation to plasmin and demonstration of a possible inter- mediate compound. Eur J Biochem 1973;36:25-31.

${ }^{27}$ Summaria L, Arzadon L, Bernabe P, Robbins KC. The activation of plasminogen to plasmin by urokinase in the presence of the plasmin inhibitor trasylol. J Biol Chem 1975;250:3988-95.

${ }^{28}$ Summaria L, Boreisha IG, Arzadon L, Robbins KC. Activation of human glu-plasminogen to glu-plasmin by urokinase in presence of plasmin inhibitors. J Biol Chem 1977;252:3945-51.

${ }^{29}$ Claeys H, Vermylen J. Physico-chemical and proenzyme properties of $\mathrm{NH}_{2}$-terminal glutamic acid and $\mathrm{NH}_{2}$-terminal lysine human plasminogen. Influence of 6-aminohexanoic acid. Biochim Biophys Acta 1974;342:351-9.

${ }^{30}$ Violand BN, Castellino FJ. Mechanism of the urokinase-catalyzed activation of human plasminogen. J Biol Chem 1976;251:3906-12.

31 Wallén P, Iwanaga S. Differences between plasmic and tryptic digests of human S-sulpho-fibrinogen. Biochim Biophys Acta 1968;154:414-7.

32 Troll W, Sherry S, Wachman J. The action of plasmin on synthetic substrates. J Biol Chem 1954;208:85-93.

${ }^{33}$ Christensen U, Müllertz S. Mechanism of reaction of human plasmin with $\alpha-\mathrm{N}$-benzoyl-L-arginine-pnitroanilide. Biochim Biophys Acta 1974;334:187-98.

34 Weinstein MJ, Doolittle RF. Differential specificities of thrombin, plasmin and trypsin with regard to synthetic and natural substrates and inhibitors. Biochim Biophys Acta 1972;258:577-90.

${ }^{35}$ Wiman B. Primary structure of the B-chain of human plasmin. Eur J Biochem 1977;76:129-37.

${ }^{36}$ Summaria L, Hsieh B, Groskopf WR, Robbins KC. The isolation and characterisation of the S-carboxymethyl $\beta$ (light) chain derivative of human plasmin. $J$ Biol Chem 1967;242:5046-52.

${ }^{37}$ Sottrup-Jensen L, Claeys H, Zajdel M, Petersen TE, Magnusson S. The primary structure of human plasminogen: isolation of two lysine-binding fragments and one 'mini-' plasminogen (MW 38 000) by elastase-catalyzed-specific limited proteolysis. In: Davidson JF, Rowan RM, Samama MM, Desnoyers PC, eds. Progress in chemical fibrinolysis and thrombolysis, vol 3. New York: Raven Press, 1978:191-209.

${ }^{38}$ Donaldson VH. Effect of plasmin in vitro on clotting factors in plasma. J Lab Clin Med 1960;56:644-51.

${ }^{39}$ Pasquini R, Hershgold EJ. Effects of plasmin on human factor VIII (AHF). Blood 1973;41:105-11.

${ }^{40}$ Pillemer L, Ratnoff OD, Blum L, Lepow IH. The inactivation of complement and its components by plasmin. J Exp Med 1953;97:573-89.

${ }^{41}$ Mirsky IA, Perisutti G, Davis NC. Destruction of glucagon, adrenocorticotropin and somatotropin by human blood plasma. J Clin Invest 1959;38:14-20.

42 Wiman B, Collen D. Molecular mechanism of physiological fibrinolysis. Nature 1978;272:549-50.

${ }^{43}$ Mackie M, Bennett B, Ogston D. A comparative study of the activators of plasminogen of human origin. In: Davidson JF, Cěpélak V, Samama MM, Desnoyers PC, eds. Progress in chemical fibrinolysis and thrombolysis, vol 4. Edinburgh: Churchill Livingstone, 1979:20-4. 
${ }^{44}$ Camiolo SM, Thorsen S, Astrup T. Fibrinogenolysis and fibrinolysis with tissue plasminogen activator, urokinase, streptokinase-activated human globulin and plasmin. Proc Soc Exp Biol Med 1971;38:277-80. 